International Journal of Agriculture, Environment and Bioresearch

Vol. 4, No. 03; 2019

ISSN: $2456-8643$

\title{
CONTRIBUTION OF AVOCADOES TOWARDS FOOD SECURITY IN EVURORE DIVISION EMBU COUNTY, KENYA
}

\author{
Moses Kathuri Njeru \\ Department of Environmental Sciences and Resources Development,Chuka University ,P.o Box 109-60400 Chuka \\ Eugenio Ireri Nyaga \\ Department of Religious Studies ,Kenyatta University ,P.o Box 109-60400 Chuka \\ http://doi.org/10.35410/IJAEB.2019.306317
}

\begin{abstract}
Having enough food and in the right amount throughout the year is a great concern world over. Indigenous crops greatly contribute to food security. Avocado is one source of food that could be used to enhance food security in the famine prone region of Evurore Division of Embu County, Kenya. Despite enhanced effort to promote avocado farming and consumption among households in the division, food insecurity remains real. The Study established that avocado has not been effectively used to enhance food security in Evurore division
\end{abstract}

Keywords: Food Security, Avocado

\section{INTRODUCTION}

\subsection{Background to the Study}

The World Food Summit of 1996 defined food security as existing when all people at all times have access to sufficient, safe and nutritious food to maintain a healthy and active life (Clay \& Hans, 2006). Food security is realized through activities of food production, storage and imports. The National Food and Nutrition Policy identifies food security as a basic human right (Republic of Kenya, 2008). Food security assists in boosting other spheres of the country's economy and thus contributing to the general development of a country. This is so because it is only a food and nutrition secure citizenry that can effectively participate in socio-economic activities.

The first of the eight Millennium Development Goals set in 2000 in Geneva, pointed out the need to eradicate extreme hunger and poverty by 2015 (Republic of Kenya, 2007). All United Nations (UN) member states pledged to reduce by half the proportion of those suffering from extreme hunger (ibid, 2007). Twelve of the Sustainable Development Goals (SDGs) especially zero hunger, no poverty, sustainable cities and communities will be achieved if agriculture is well developed (United Nations Development Programme [UNDP], 2015). However, food insecurity in the $21^{\text {st }}$ century is still a global challenge. For example, in Kenya there are many people suffering from food insecurity who go to bed hungry or cannot afford three meals a day (Kenya National Bureau of Statistics, 2010. 
Africa is essentially an agricultural continent, but its performance on food production has been poor as manifested by a series of famines (Chole, 1990). More than eleven million people are in dire need of food in the Horn of Africa. In most countries this food shortage is as a result of prolonged droughts that cause massive crop failure and death of livestock. This is experienced in countries such as Somalia, Ethiopia, Kenya and Sudan. It is estimated that 51 per cent of Kenya's population is undernourished. Food insecurity is a common phenomenon among many communities in Kenya. This is experienced mostly in the rural areas where about $80 \%$ of the country's population lives (Kenya National Bureau of Statistics, 2010).

However, many parts of Kenya have continued to suffer food shortage, despite many government policies put forward. Basing on the recurrent food shortage in many parts of Kenya, it is clear that the policies laid down in the papers have not effectively improved food situation in the country. Communities are yet to be sensitized on ways of increasing production, utility and preservation of their food crops. For example the famers in Evurore division grow other crops such as millet, sorghum and peas which they also regard as important food crops.

This brings us to a review of food security issue in Mbeere. This study hopes to bring some sustainable way of enhancing food security in Mbeere sub-County, Embu County.

\subsection{Statement of the Problem}

The Catholic Diocese of Embu has initiated several projects in the diocese aimed at increasing food production in the region. These include crop farming and livestock keeping. Avocado fruit is one of the most valuable crops grown in the region and also propagated by the diocese. Avocado do well in low rainfall and its uses are quite diverse. However, food insecurity has remained a common phenomenon in the Evurore division despite the concerted effort by stakeholders in initiating several projects and avocado being grown in the region. In view of the above, this study examines the role of avocado towards enhancement of food security in Evurore division.

\subsection{Study's Objectives}

The specific objectives of the study were as follows: -

i) To establish the causes of food insecurity in Evurore Division in Mbeere North sub-county.

ii) Find out the Ambeere religio-cultural beliefs and practices that affect the production and consumption of avocado in the enhancement of food security in Evurore division.

\section{RESEARCH METHODOLOGY}

\subsection{The Study Area}

The locale of the study was Evurore Division, Mbeere North sub-county, Embu County, Kenya. The area covers about 410 square kilometers. The division has a population of approximately 45,582 persons with about 10,317 households (Kenya Bureau of Statistics, 2010). It is located along the Embu-Ishiara road. The choice of this area was based on the fact that it has better soils for farming than other divisions of Mbeere Sub-county yet it is affected by food insecurity. The 
area has also the highest production of avocado. There are four locations in the division; Ishiara, Kanyuambora, Kiang'ombe and Ndurumori. The study was carried out in Kanyuambora and Ishiara Locations which have the highest production of avocado yet, they experience severe food shortage.

\subsection{Research Design}

The study used qualitative research design because it is concerned with qualitative phenomenon (Kothari, 2004). In this case the researcher was investigating the perception of Evurore community on the causes of food insecurity among their households. There was no manipulation of variables.

\subsection{Sampling Techniques}

The study employed a simple random sampling where farmers were individually chosen randomly. Since the target population of farmers was large the researcher used $14 \%$ of the target population of famers to get a sample size of 70. Mugenda and Mugenda (2003) notes that a representative sample is one which is at least $10 \%$ to $30 \%$ of the population thus the choice of $14 \%$ is considered as a representative of the population. In this study the total sample size of the respondents was 96 . The following are the main categories of respondents:

\subsection{Instruments and data Collection}

Questionnaires (structured and open ended) for development coordinators and some few farmers were used for data collection. Interview guide and FGDs was used for farmers and some individual farmers from Evurore division. They systematically elicited information the causes of food insecurity in Evurore division and the religio-cultural factors influencing the utilization of avocado. Before conducting any interview or administering the questionnaire, the researcher introduced himself and explained the purpose of the study to the potential respondents. The respondents were assured that all the information provided was purely for academic purposes and not for any other reason.

\subsection{Data Analysis}

This study largely applied the qualitative method of data analysis. The data was organized according to the study objectives that were covered in the instruments. It was then summarized and organized into themes pertinent to the study.

\section{RESULTS AND DISCUSSIONS}

\section{1 Causes of food insecurity in Evurore Division}

The study sought to find out the possible causes of food insecurity among the residents of Evurore division and the respondents gave their views as discussed hereunder.

\subsection{Drought as a Cause of Food Insecurity in Evurore Division}

Drought is a phenomenon that exists when precipitation has been significantly below normal recorded levels causing a serious hydrological imbalance that adversely affects land resource production systems. Kenya is among countries prone to climatic change, which makes it 
somehow challenging to predict the weather patterns. The United Nations Development Programme (UNDP, 2002) pointed out that almost 70 percent of Kenya's land mass is affected by drought.

Table 1 Response on drought as a cause of food insecurity in Evurore division

\begin{tabular}{|c|c|c|c|c|c|c|c|c|c|c|}
\hline \multirow[t]{2}{*}{ Response } & \multicolumn{2}{|c|}{ Very high } & \multicolumn{2}{|c|}{ High } & \multicolumn{2}{|c|}{ Average } & \multicolumn{2}{|c|}{ Low } & \multicolumn{2}{|c|}{ Very low } \\
\hline & $\mathrm{F}$ & $\%$ & $\mathrm{~F}$ & $\%$ & $\mathrm{~F}$ & $\%$ & $\mathrm{~F}$ & $\%$ & $\mathrm{~F}$ & $\%$ \\
\hline Priests & 3 & 50.0 & 2 & 33.3 & 2 & 1 & 16.7 & 0 & 0 & 0 \\
\hline $\begin{array}{l}\text { Project } \\
\text { coordinators }\end{array}$ & 11 & 55.0 & 6 & 30.6 & 2 & 10.0 & 1 & 5.0 & 0 & 0 \\
\hline Farmers & 40 & 57.1 & 20 & 33.6 & 6 & 10.0 & 4 & 5.0 & 0 & 0 \\
\hline
\end{tabular}

The findings on Table 1 revealed that most priests, coordinators, and farmers, rated drought very high and high as the cause of food insecurity. It should be noted that those who rated drought very high were above 50 percent. From these responses it is clear that most people in Evurore Division view drought as the main cause of food insecurity in the region. They argued that the area is very dry with scanty and unreliable rainfall most of the time. They added that in most cases the rains end before crops mature hence the farmers get very little or no yields at all. This eventually discourages the farmers hence some of them end up abandoning cultivation for alternative ways of survival.

Farmers who rated drought as high noted that some pockets of the region such as Kanyuambora location experience fair harvest while the lower zones of Ishiara get poor harvest. However, they maintained that most parts of the area experience poor rainfall patterns. The farmer's view support Oniang'o's (1988) view that unfavorable climatic conditions have significant impact on crop production which eventually leads to food insecurity. Oniang'o added that about 15 per cent of Kenya's land is arable, but harsh weather conditions jeopardize food production. Their responses also affirm the premise that drought is a major cause of food insecurity in Evurore.

The unpredictable weather pattern has made drought a major cause of food insecurity especially in semi-arid areas in Kenya. Mbeere north sub-district lies in a semi-arid region in Eastern Kenya. The region receives an average of $750 \mathrm{~mm}$. of rain per annum. For this reason, drought is a frequent phenomenon in the region. Prolonged drought dries food crops and water resources. Drought also leads to deaths of livestock (Republic of Kenya, 2007).

Those rating drought low felt that even when there is plenty of rainfall in the division, a good number of people still complain of lack of food. They suggested that food insecurity should be looked at beyond drought. They thus support the argument by Cohen (2005) that drought is not the main cause of food insecurity since there are other ecological factors which are beyond human control. Furthermore, drought is a natural phenomenon that can be predicted and necessary precaution taken to avert its effects such as food insecurity. 
They do not get the right advice on when to plant and the appropriate crop variety for the season. The farmers thus plant at the wrong time and even plant inappropriate crop variety for the season. The study also noted that Kenyans do not prepare for drought despite the warning. This information is never disseminated to the poor farmers in the rural area. The information is also given in the language only understood by the elite or the specialists in the agricultural sector. Worse still even some of the agricultural officers do not interpret the message correctly and even if they do, it is not passed to the farmers.

Many farmers noted that they could not remember when they ever received adequate rain-fall. They observed that, due to the unreliable rainfall, they have been discouraged from tilling their land because they have to buy seeds, expend their labour but get low yields or none at all. Those who rated drought as high observed that large parts of the division do not receive adequate rainfall leading to massive crop failure. Those respondents who rated drought as average observed that they had tried to put in place some measures to mitigate them from the effects of drought. Such measures included small scale irrigation, planting drought-resistant crops such as cassava, millet and sorghum.

\subsection{Lack of knowledge and poor farming practices among farmers in Evurore Division}

According to UNEP and GoK (2000), the level of literacy and understanding of hazards has been low in drought-prone areas as compared to other parts of the country. The harsh weather conditions compounded by traditions and beliefs form a major setback on educational achievement. According to Save the Children (UK) Nutrition Survey (2010) in Mandera subCounty, low literacy means limited skills, knowledge and innovativeness, a factor that has inhibited the pursuit of alternative livelihoods. The result is that most of the residents are trapped in the low productivity traditional pastoralist economy.

Lack of proper knowledge of farming practices has resulted in low crop yield and also crop loss after harvest leading to food shortage. For example, some farmers pointed out that application of fertilizers in their farms would destroy their soil. Hence they prefer planting without fertilizers. The participants' responses on ignorance and poor farming practices are summarized on Table 2 presents

Table 2 Knowledge and poor farming practices as causes of food insecurity in Evurore Division

\begin{tabular}{|c|c|c|c|c|c|c|c|c|c|c|}
\hline \multirow{2}{*}{$\begin{array}{l}\text { Respondent } \\
\text { Frequency }\end{array}$} & \multicolumn{2}{|c|}{ very high } & \multicolumn{2}{|c|}{$\underline{\text { high }}$} & \multicolumn{2}{|c|}{ Average } & \multicolumn{2}{|c|}{ Low } & \multicolumn{2}{|c|}{ Very low } \\
\hline & $\mathrm{F}$ & $\%$ & $\mathrm{~F}$ & $\%$ & $\mathrm{~F}$ & $\%$ & $\mathrm{~F}$ & $\%$ & $\mathrm{~F}$ & $\%$ \\
\hline Priests & 1 & 16.7 & 3 & 50.0 & 2 & 33.3 & 0 & 0 & 0 & 0 \\
\hline $\begin{array}{l}\text { Project } \\
\text { coordinators }\end{array}$ & 9 & 45.0 & 7 & 35.0 & 4 & 20.0 & 0 & 0 & 0 & 0 \\
\hline Farmers & 33 & 47.1 & 28 & 46.7 & 7 & 11.7 & 2 & 33.3 & 0 & 0 \\
\hline
\end{tabular}


Information on Table 2 shows that project coordinators and farmers rating trend was similar. Most coordinators and farmers rated lack of knowledge and poor farming practices as Very High. They observed that most farmers lacked knowledge on farming practices such as the use of fertilizers and modern methods of keeping livestock.

It is this ignorance that caused massive crop failure in many parts of Kenya including Evurore Division in 1978. Munene the Catholic Diocese of Embu Integrated Rural Development Programme (IRDP) Coordinator observed that, despite efforts by the church to enlighten farmers on modern methods of farming, most of them still cling to their traditional methods. Farmers expressed unwillingness to change, arguing that they had practiced their traditional methods for long before and had good harvests.

Some farmers observed that lack of adequate information on the weather patterns resulted in massive crop failure. For example, Njue cited the 1997 incident of El-Niño rains where food production was doing very well in the field but rains came just a week before they could harvest and destroyed all the beans. Farmers had expected a dry spell in early January to harvest beans and peas. The meteorological department however, failed to alert them of the heavy rains that came in January 1998, contrary to the usual dry weather pattern. If the farmers had prior information that the rain would come early in January, they could have harvested in December before the rains. The unusual rain caused a lot of damage in the agricultural sector. Ireri observed that the year 1998 was an exceptional one because he had very high hope of a bumper harvest in beans. Unfortunately, when the rains returned all his hopes were dashed. The dry beans were rained on in the farm making it difficult to harvest. Even what he was able to salvage from the farm became waste because it could not dry due to the wet weather. Eventually all his harvest went to waste.

Fr. Njeru from Kirie Catholic parish observed that the residents of Evurore lack knowledge on modern farming methods that could increase food production. For example, River Ena which is a permanent river passes through the region and even those who live next to it do not exploit its waters for irrigation. Ngithi argued that farmers especially in the lower Ishiara location are not adequately informed about some important information relating to farming. Many of them are not aware of the onset of rain. When they plant late, the crops end up receiving very little amount of rainfall and therefore dry up before they mature. Ngithi also noted that some farmers do not use manure or fertilizers to increase soil fertility and thus boost their crop yields. This is because they believe that using fertilizers in their farms would destroy their soil fertility or pollute their soils. This eventually results in poor crop yield.

A respondent from Gwakaithi parish noted that some farmers had knowledge on how to take good care of their crops and livestock and were able to obtain reasonable return. This is why the priest rated ignorance as average. Kiraithe a farmer at Murari village observed that they have read from the papers about the export market for avocado but they had not benefitted. This is because they sell their fruits at home to middle men or in the local market at a very low price which does not benefit them. 
From the farmers' response, it is clear that Evurore residents lack sufficient information on better methods of farming. This ignorance has greatly contributed to food shortage in the recent past in Kenya. For example many farmers use broadcasting method in planting millet. The broadcasting method is not scientific and seeds are planted without consideration of space and seed rate. There is also no application of fertilizers. Farmers are advised to use the modern method of roll planting as opposed to the broadcasting one. The roll method ensures maximum utilization of the land and the available plant nutrient since crops are spaced enough and do not compete over nutrients.

\subsection{Poverty and laxity in Farming among Evurore Community Members}

Kenya is a country of many contrasts, from its landscape to demographics, and more so it's social and economic inequalities. Kenya is one of the most unequal countries in the sub-region. 42 per cent of her population of 44 million live below the poverty line. On the other hand a good number also enjoy luxuriant life. Access to basic quality services such as health care, education, clean water and sanitation, is often a luxury for many people. Large segments of the population, including the burgeoning urban poor, are highly vulnerable to climatic, economic and social shocks. As such, progress on the Millennium Development Goals, especially in regards to social security, is mixed (UNCEF, 2016).

In Mbeere, livestock keeping and subsistence farming are the main sources of income for most of the households. Additionally, other residents are engaged in self-employment and wage employment. However their Gross Domestic Product (GDP) remains low. Jane who is a teacher noted that due to lack of any meaningful economic activities, many residents of Evurore sell their livestock to cater for the basic needs at home. Eventually, they are left without any tangible asset to depend on in times of economic crisis. Consequently, this increases the level of food insecurity. Friedman (1992), who is described as a promoter of what he calls "alternative development" describes poverty by focusing on powerlessness as lack of access to social power. He notes that in a social development people exclude poor households. He further observes that poverty is related to lack of access to social power. Due to being powerless, the poor cannot make any reasonable bargain of their resources including their own human resource and so end up being paid very low wage.

Chambers (1983, 103-39) describe the poor as living in a "cluster of disadvantage". The household is poor, with nothing to save and so they are vulnerable to eventualities such as drought or other climatic related phenomena or price hike by traders. They also lack strength due to many dependents. They are isolated by the larger society and thus lack education or valuable knowledge on farming methods and so their produce is usually poor. He also notes that the poor are vulnerable, powerless and easy to be coerced. They are entangled in a system which Chambers call "poverty trap." Table 3 shows responses on poverty as a cause of food insecurity.

Table 3Poverty and laxity as a cause of food insecurity in Evurore Division

\begin{tabular}{|c|c|c|c|c|c|c|c|c|c|c|}
\hline \multirow[t]{2}{*}{ Respondent } & \multicolumn{2}{|c|}{ Very High } & \multicolumn{2}{|c|}{ High } & & rag & \multicolumn{2}{|c|}{ Low } & \multicolumn{2}{|c|}{ Very Low } \\
\hline & $\mathrm{F}$ & $\%$ & $\mathrm{~F}$ & $\%$ & $\mathrm{~F}$ & $\%$ & f & $\%$ & $\mathrm{~F}$ & $\%$ \\
\hline
\end{tabular}




\begin{tabular}{|lllllllllll|}
\hline Priests & 1 & 16.7 & 4 & 66.7 & 1 & 16.7 & 0 & 0 & 0 & 0 \\
Project Coordinators & 4 & 20.0 & 12 & 60.0 & 4 & 20.0 & 0 & 0 & 0 & 0 \\
Farmers & 25 & 41.7 & 40 & 57.1 & 5 & 8.3 & 0 & 0 & 0 & 0 \\
\hline
\end{tabular}

Information in Table 3 shows that all the participants responded to the three higher categories of Very High, High and Average only; none of them responded to Low or Very Low. This is an indication that poverty adversely affects food security in the division. Most respondents observed that poverty was a major cause of food insecurity. They responded as follow: priests (66.7 per cent), coordinators (60.0 per cent), and farmers (57.1 per cent).

Among the farmers, high was the first in rating (57.1 per cent), Very High second (41.7 per cent) while Average was rated last with $(8.3$ per cent). Some farmers claimed that they work hard in their farms although they get low crop yield. It could therefore be observed that poverty contributes significantly to food insecurity in the division. The priest who mentioned High noted that the cost of inputs such as fertilizers and seeds has gone up impacting negatively on the farmers, especially the poor ones in the region. The priest noted that even when the area receives adequate rainfall, many farmers could not afford to buy high quality certified seeds. This eventually results in poor crop yield despite adequate rainfall.

The Diocese coordinators had similar sentiments with those of the priest that poverty contributed enormously to food insecurity since many farmers cannot afford farm inputs. Igoki (O.I, 2009), a farmer in Kavengero village, Kanyuambora location observed that certified seeds and cattle feeds are unaffordable to most farmers and so they use cheap methods of crop farming and livestock rearing. This is simply working with the available resources. The farmers plant seeds that are not certified from the shops. On the side of the cattle, they graze their animals on the natural pasture without going for the concentrates or the dairy feeds.

Some farmers observed that they are very discouraged by the high cost of inputs and cattle feeds and other farm inputs. This has made some farmers to abandon farming and turn to other modes of livelihood. According to Ngochi the residents of Evurore plant the seeds that they have at their disposal regardless of their viability. Most of them do not bother to go for the certified seeds from the shop. In addition, they do not use fertilizers when planting or to top-dress. Eventually they get very low yields leading to food insecurity. These farmers are sometimes to blame for their fate. They have dug their own grave because of their ignorant. As Boff and Pixley (1989) observes the poor resign themselves passively to their poverty or seek an egotistical liberation. They lack hope and unable to believe that change is possible and so they can do nothing about their fate.

Munene observed that many farmers lack adequate structures to store their produce. Due to poverty level farmers are unable to build efficient stores that keep away rodents, and ants. Farmers are also not keen on how they store their produce after harvest. According to the United Nations Food and Agricultural Organization (FAO) 24 per cent of the food loss is at the postharvest stage. 
There were some farmers who stated that they find it easier to work in other people's farms for a day's wage than struggle to buy inputs for their farms that do not pay back. They prepare very little for the rains and in many occasions they plant late and also weed after working in other peoples' farms. This leads to poor harvests in their farms. A respondent noted that casual jobs had kept him away from tending to his farm; thus resulting in poor harvest. Other farmers observed that the youth in Mbeere have developed a negative attitude towards food crop farming. They have even given up doing manual work in the farms since they have not realized benefits from the farm. The youth who could do farming in the rural areas have despised and abandoned farming leaving it to their parents who have little knowledge on modern farming methods.

\subsection{Inadequate Policies on Food Production}

Food policies are formulated by the government to increase the production and utility of crops. Food insecurity in Kenya has prompted the government to formulate numerous policies for the purpose of increasing food production in the country. For example, the Session Paper Number 4 of 1981, on National Food Security Policy was meant to ensure adequate supply of food to all parts of Kenya at all times. It recommended the growing of drought resistant crops, especially in the arid and semi-arid areas to ensure adequate supply of food in all parts of Kenya. The paper also recommended food processing, as an ideal measure for providing all regions of Kenya with food required at the lowest levels. This policy seems not to have yielded fruits in Evurore Division because the community grows the usual drought resistant crops but do not get reasonable yield. At the same time, farmers grow mangoes, paw paws and avocado, but the government has not initiated fruit processing plants. Farmers sell their produce at very low prices while others perish in the farm. The National Food Security and Nutrition Policy (2010), was meant to increase the quantity and quality of food available to all Kenyans at all times. However, food insecurity in Evurore has however remained persistent.

A poor crop yield could be as a result of environmental factors. Kamau vividly recalls the 198182 famine which they named "Ningua ngwete" (I will die holding) which literary meant; people starved to death even though they held money but there was no food to buy. The residents survived on food donations from the Government and the Catholic Diocese of Embu. The long drought was followed by the heavy El Niño rains in 1986. The residents asserted that even with the presence of the heavy rains, no agricultural officer advised them on what they could do to increase food production. For example, the heavy rains lasted for a longer time than normal but they did not benefit from it because they lacked the necessary information to harness the rains for increased food production. The residents planted the usual short rain crop variety that is affected by high rainfall.

Food production, just as food shortage is not always evenly distributed in a region. For instance in a region that is faced with food shortage, there could be some households that are well endowed with food production. In Kenya, parts of Rift Valley, Eastern and North Eastern provinces are often faced with famine yet in other areas in Central, Rift Valley and Western provinces receive bumper harvest that at times goes to waste because of the challenges in postharvest practices. The Food Safety and Quality Control Policy was meant to create public awareness, setting, promoting and enforcing appropriate guiding standards and a regulatory 
framework to enhance food production. However, this did not assist Evurore community. In Evurore, the responses of the people with regard to policies are presented in Table 4.

Table 4 Response on Inadequate policies as a cause of food insecurity in Evurore division

\begin{tabular}{|c|c|c|c|c|c|c|c|c|c|c|}
\hline \multirow[t]{2}{*}{ Respondent } & \multicolumn{2}{|c|}{ Very High } & \multicolumn{2}{|c|}{ High } & \multicolumn{2}{|c|}{ Average } & \multicolumn{2}{|c|}{ Low } & \multicolumn{2}{|c|}{ Very Low } \\
\hline & $\mathrm{F}$ & $\%$ & $\mathrm{~F}$ & $\%$ & $\mathrm{~F}$ & $\%$ & $\mathrm{~F}$ & $\%$ & $\mathrm{~F}$ & $\%$ \\
\hline Priests & 0 & 0 & 1 & 16.7 & 3 & 50.0 & 2 & 33.3 & 0 & 0 \\
\hline Project Coordinators & 0 & 0 & 1 & 5.0 & 11 & 50.0 & 6 & 30.0 & 2 & 10.0 \\
\hline Farmers & 0 & 0 & 6 & 8.5 & 21 & 35.0 & 36 & 51.4 & 7 & 10.0 \\
\hline
\end{tabular}

Information on Table 4 shows that none of the participants rated inadequate policies as significant cause food insecurity. The priests and Coordinators trend of response was similar. Most priests (50 per cent), and coordinators (55 per cent), identified it as average or Low implying that they did not regard it as a serious contributor to food insecurity.

Those farmers who rated inadequate policies as average observed that the government had come up with some policies and land tilling patterns to prevent soil erosion and encourage farmers to grow drought-resistant crops such as cassava and millet. However, there was no follow-up to ensure that the policies are actually implemented. Those who rated inadequate policies as low noted that the problem of food insecurity in Evurore division go beyond policies. This is because the area experiences persistent drought and abject poverty that makes it hard for the locals to engage in farming. The above discussion shows that there are no specific policies in the region that could ensure sustainable solutions to the problem of food shortage.

The priests and coordinators responses appeared to support (Mohamed, 1994) who assert that food insecurity, in the African continent is largely induced by misconceived food policies; and also the difficulties within which they have been developed. The farmers observed that the problems of lack of food in the area had to do with weather patterns and poverty. Most of them cannot afford to buy inputs such as certified seeds, fertilizers, pesticides and proper farm equipment. The farmers also pointed out that the cattle feeds are too expensive for them to buy.

\section{REFERENCES}

Boff, C \& Pixley, G. (1989). Bible The Church and the Poor.New York Obis Books.

Byrne,T (1983). Integral Development. Development of the Whole Person. Ndola-Zambia, Mission Press.

Chambers, R. (1983).Rural Development: Putting the Last First. London, Longman Group.

Chambers, R. (1997). Whose Reality Count: Putting the First Last. London, Intermediate Technology Publishers. 
Chola, E. (ed), (1990). Food Crisis in Africa. India, Vikas Publishing Horse.

Clay, E. \& Hans, H. (2006).Food Aid and Development. London, Stanford University Press.

Jammal, T. \& Ernest, J. (1981). Advances in Food Producing Systems for Arid And Semi-Arid Land. (Part B). New York: Academic Press.

Kothari, C. (2004). Research Methodology: Methods and techniques New Delhi. New Age International Publishers.

Mkandawire, N, and Bourenane, T. (1987). The State and Agriculture in Africa. London, Codesria Publishers.

Mohammed, S. (ed), (1994). Inducing Food Insecurity. Nordisky, Afrikanstitutek.

Mugenda, O. \& Mugenda, A. (2003). Research Methods: Quantitative and Qualitative Approaches. Nairobi, African Centre for Technology Studies.

Republic of Kenya. (2007). National Policy for the Sustainable Development of ASALs of Kenya.4th Draft, Nairobi Kenya.

Republic of Kenya. (2011). Poverty Reduction Strategy Paper for the Period 2001-2004. Nairobi, Department of Development Co-ordination.

Reynolds, H. \& Tannar, P. (1983). The Ecology of Religion. New York, Oxford University Press.

Santa Ana, J. (1981). Towards the Church of the Poor. New York, Obis Books.

Sikolia, B. (2001). Managing Food Security With Reference To Sabatia Food Security Project. Nairobi: Catholic University of Eastern Africa.

Stanley, Y. \& Gleg, M. (1971). Freedom from Food Dependence. Washington. Washington Affairs Press.

Ted, K. (1985). Regional and Seasonal Food Problem in Kenya. Report on Food And Nutrition Program. Nairobi, Ministry of Finance.

Theodor, H. (1991). Catholic Social Teaching. London: New City.

United Nations Environmental Programme and Govermnent of Kenya (2000.). Devastating Drought in Kenya, Nairobi. Environmental Impacts and Responses. 
International Journal of Agriculture, Environment and Bioresearch

Vol. 4, No. 03; 2019

ISSN: $2456-8643$

Waugh, D. (1995). Geography: An Integrated Approach. Ontario, Thomas Publications.

William, A. (1990). Cultural Anthropology. Chicago, Holt, Rinehart and Winston. https//www.standardmedia.co.ke (Accessed on 11.01.2012).

Wizba, N. (2011.) Food and Faith. A Theology of Eating. New York, Cambridge University Press. 